Journal of the

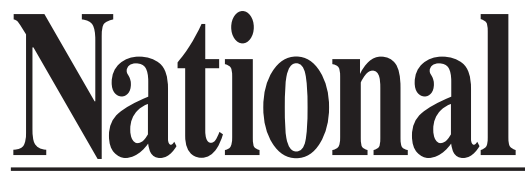

Academy or

Forensic
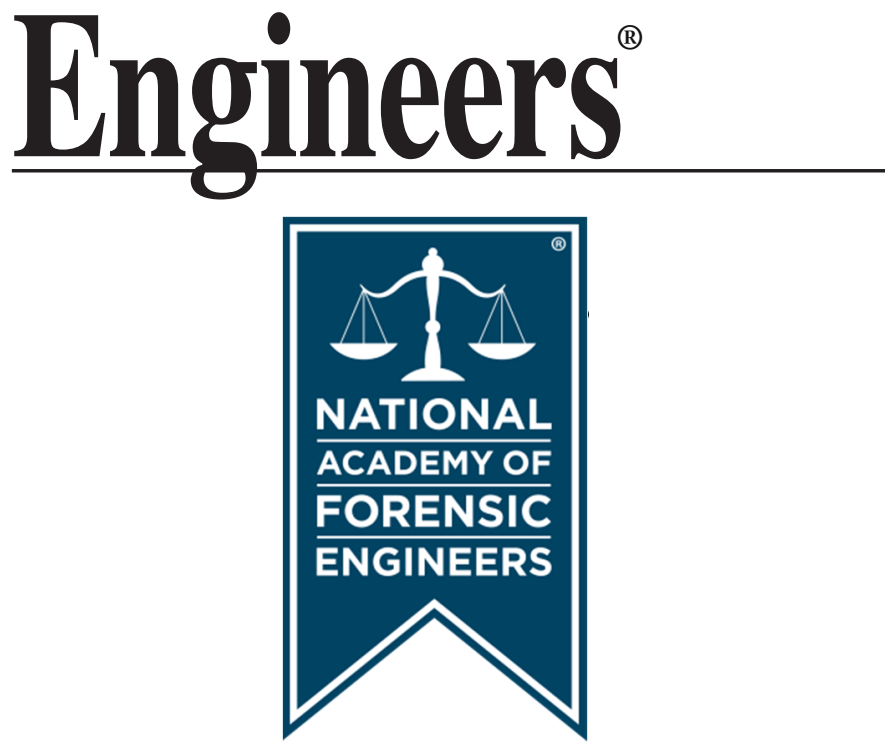

http://www.nafe.org ISSN: 2379-3252 


\section{Forensic Engineering Analysis of Building Codes and Staircase Accidents}

by Michael Kravitz, P.E. (NAFE 451S)

\section{Introduction}

The history of building codes dates back to between 2200 and 1700 B.C. The first known codes were the Codes of Hammurabi. The Hammurabi Codes were simple. If a builder builds a house and the house collapses and kills the owner, then the builder shall be put to death. If the collapsed house kills the owner's son, then the builder's son shall be put to death. If the collapsed house ruins goods, then the builder shall make compensation, and so on. The codes were based on the, "An eye for an eye" system of justice. The officials of ancient Athens had the power to condemn unsafe buildings. In Rome approximately 27 A.D., the collapse of the amphitheater resulted in laws regarding public buildings. In 1189 the Assize of Buildings, which was an ancient species of court, consisting of a certain number of men, usually twelve, who were summoned together to try a disputed cause, performing the functions of a jury, except that they gave a verdict from their own investigation and knowledge and not upon evidence offered. ${ }^{1}$ The Assize of Buildings enacted codes that required fire walls to be three feet thick and sixteen feet high. In 1630, in Boston, laws were enacted that prohibited chimneys from being constructed with wood and roofs from being constructed of thatch. In 1865 in New Orleans laws were enacted that required the inspection of public places. In 1897 the National Electric Code was created. In 1905 the National Board of Fire Underwriters published the first recommended National Building Code. In 1927 the Pacific Coast Building Officials Conference published the Uniform Building Code. In 1945 the Southern Building Code Congress International published the Uniform Building Code. In 1950 the Building Officials Conference of America published the Basic Building Code. Presently, there are several building code organizations:

- Southern Building code Congress International (SBCCI) www.sbcci.org

- International Conference of building Officials (ICBO) www.icbo.org

- Building Officials and Code Administrators International (BOCA) www.bocai.org

- Council of American Building Official (CABO) www.intlcode.org 
- International Code Council (ICC)

- International Code Council (ICC) developed the 1998 International

- One/Two Family Dwelling code from the 1995 Edition of (CABO)

- International Residential Code (IRC)

- Ohio Basic building Code (OBOA) www.obca.org

This paper will discuss the importance of determining the history of a building where a mishap occurred on either an interior or exterior staircase. The writer's experience is primarily in the City of New York, however, the research and types of laws cited in this paper can be used as a guide in the research of all cities, especially older cities such as Boston, Philadelphia, Baltimore, Chicago, Charleston, Atlanta, New Orleans, San Francisco, etc. Researching a buildings history is the primary task of the forensic engineer whether he is preparing a case for either the plaintiff or defense. Citing the correct codes will insure that his opinion will be accepted by the court. It must be understood that the owner of a building is responsible to maintain his/her building to the codes to which it was built unless a directive was issued by the building department to the contrary, or a directive that required the owner to comply with current codes.

\section{The Building Code History of the City of New York}

The building code history of the City of New York began circa 1625 when the Dutch West India Company established rules for houses built by the colonists. The rules required the house to be built for public safety and sanitation. By 1674 there were laws that governed construction, fire prevention and sanitation within the city. In 1860 there was a tenement house fire that claimed the lives of twenty persons. As a result, in 1862 the City of New York adopted regulations and inspection procedures of buildings and tenements. The full title of the Act was as follows;

AN ACT TO PROVIDE FOR THE REGULATION AND INSPECTION OF BUILDINGS, THE MORE EFFECTUAL PREVENTION OF FIRES, AND THE BETTER PRESERVATION OF LIFE AND PROPERTY IN THE CITY OF NEW YORK, Passed April 19, 1862, Also, AN ACT IN RELATION TO THE KEEPING OF GUNPOWDER, SALTPETER, AND CERTAIN OTHER SUBSTANCES, IN THE CITY OF NEW YORK, AND ORDINANCES TO PREVENT THE STORAGE OF FIRE-WORKS, AND RELATIVE TO HOISTWAYS, TOGETHER WITH EXTRACT FROM AN ORDINANCE FOR PREVENTING AND EXTINGUISHING FIRES IN THE CITY OF NEW YORK. 


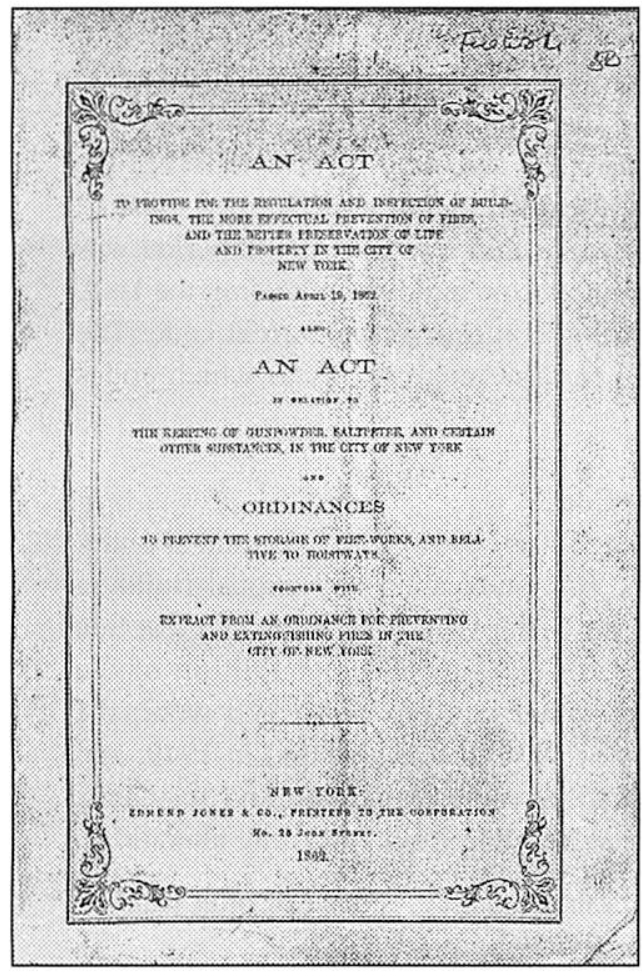

It should be noted that the Act of 1862 did not specify dimensions of stairs, or whether stairs should have handrails, nor did it give any dimensions for treads and risers, nor any of the requirements that would appear in modern codes.

In 1865 the position of Superintendent of Buildings was created within the Fire Department to enforce new structural and safety laws. In 1882 the Building Code was instituted with revisions though the years until 1916 when the Building Code was rewritten. In 1892 the Manhattan Building Department was formed, and in 1901 the Tenement House Act was enacted. The 1882 Building Code and the Tenement House Act both were specific regarding stairs, citing dimensions for treads, risers, handrails, landings, widths of stairs, etc. The 1916 Building Code replaced the 1882 Building Code; the 1938 Building Code replaced the 1916 Building Code; and the 1968' (current) Building Code replaced the 1938 Building Code. In addition, the 1929 Multiple Dwelling Law replaced the Tenement House Act, which went through various revisions. Why are these dates important? Because the owner of a building is responsible to maintain his/her building to the code to which it was built. Except, when there is an alteration that exceeds a certain percentage of the value of the building excluding the land, or as prescribed by the current building code of the jurisdiction, or if a "Directive" was issued by the building department that required building owners to upgrade portions of their building. For example, in New York City, building owners of buildings taller than six stories were required to have the exterior facade of their building inspected by either a registered architect or professional engineer once every five years, with a report filed with the building department.

If a mishap occurred on a building staircase, the forensic engineer can not just cite the current building code "willy nilly". A history of the building would be required. For example, the current New York City Building Code is specific 
regarding alterations. If a building was altered and the alteration for a twelve (12) month period was less than thirty percent $(30 \%)$ of the value of the building excluding the land, then the alteration may be performed under the code to which the building was constructed. If the alteration, within a twelve (12) month period was between thirty percent $(30 \%)$ and sixty percent $(60 \%)$ of the value of the building excluding the land, then the alteration performed must be to the current code. Finally, if the alteration, within a twelve month period was greater than sixty percent $(60 \%)$ of the value of the building excluding the land, then the owner must have the entire building conform to the current code. The history of the building would guide the forensic engineer as to which codes would apply for the case at hand.

\section{Development of the National Building Code}

In 1903 the Iroquois Theatre in Chicago was destroyed by fire and six hundred people perished. This resulted in the first publication of National Building Code in 1905 by the National Board of Fire Underwriters. In 1906 the great San Francisco earthquake and fire occurred. In 1907 the Second Edition of the National Building Code was published. Other editions published were; the Fourth Edition in 1915; the Fifth Edition in 1934; another edition in 1949; and the Golden Edition in 1955. Each edition added more regulations and standards. The following were changes in the National Building Code regarding alterations:

- 1907 Code - Section 2 - No building raised, altered, moved or built shall be in violation of this code.

- 1915 Code - Section 1 - ..... Shall apply only to buildings or structures hereafter erected or altered.

- 1934 Code - Section 100.5 - No building or structure shall be altered that would be in violation of this ordinance.

- 1949 Code - Section 100.4(b) - No building or structure shall be altered that would be in violation of this ordinance.

- 1955 Code - Unlawful to maintain, occupy or use a building that is in violation of this code.

It was the desire of the National board of Fire Underwriters to have the various cities and towns that did not have building codes to use its code as a guide. As a matter of fact, they would leave blank spaces for a city, town or village to put its name.

\section{Southern Standard Building Code}

The Southern Standard Building Code's requirements, in part, regarding alterations is as follows: 
- 1965 Southern Standard building code: Alterations, repairs, additions;

- If more than $50 \%$ of the value of the building excluding the land within a twelve (12) month period is to be altered, then the entire building must conform to the current building code.

- If between $25 \%$ and $50 \%$ of the building excluding the land within a twelve (12) month period is to be altered, then the altered sections must comply with the current code.

- If less than $25 \%$ of the building excluding the land within a twelve (12) month period is to be altered, then the altered sections may comply with the old code.

- 1985 Southern Standard building code: Alterations, repairs, additions;

- The work being performed must comply with the Code. The Building Official shall determine the extent to which the existing system must conform to the Code.

This last requirement is an odd case where the later code was less specific than the older code. This code could lead to various interpretations as different building commissioners may interpret the work in different ways. It would be better to have a consistent standard in which everyone could rely.

\section{Uniform Building Code}

The Uniform Building Code's requirements, in part, regarding alterations is as follows:

- 1949 Uniform Building Code: Alteration, repairs, additions:

- If the alteration is more than $50 \%$ of the value of the building excluding the land within a twelve (12) month period, then the entire building must conform to the current building code.

- If the alteration is less than $50 \%$ of the value of the building excluding the land within 12 month period, then the alterations can be made to old code.

- Any structural alterations must conform to the current code.

- 1970 Uniform Building Code: Alterations, repairs, additions:

- If the alteration is more than $50 \%$ of the value of the building excluding the land within a twelve (12) month period, then the entire building must conform to the current building code.

- If between $25 \%$ and $50 \%$ of the building excluding the land within a twelve (12) month period is to be altered, then the altered sections must comply with the current code. 
- If less than $25 \%$ of the building excluding the land within a twelve (12) month period is to be altered, then the altered sections may comply with the old code.

- 1991 Úniform Building Code: Alterations, repairs, additions,

- Any structural alterations made must conform to the current code.

- Any Nonstructural alterations performed may be made to the old code.

\section{Other Building Codes}

The requirements, in part, of other building codes regarding alterations:

- 1916 South Bend, Indiana - Section 1279 - This Code provides for all matters of construction, remodeling, alteration, repairing, moving or removal of buildings....

- 1920 Haverford Township, Delaware County, Pennsylvania - An alteration to a structural part shall comply with the code. Renewal or replacement of a worn out or broken part is not an alteration.

- 1923 City of Elmira, New York - No building or structure shall be altered that would be in violation of this ordinance.

- 1928 Village of New Hyde Park - New York - No building or structure shall be altered that would be in violation of this ordinance.

- 1939 Poughkeepsie, New York - No building or structure shall be altered that would be in violation of this ordinance.

1942 Franklin County, Ohio -

- If an alteration exceeds $50 \%$ of building value within a 12 month period, then the entire building shall conform to current code.

- If an alteration falls between $25 \%$ and $50 \%$ of the building value within a 12 month period, then the altered sections must comply with the code.

- If an alteration is less than $25 \%$ of the building value within 12 month period, then the altered sections may comply with old code.

- 1947 Scotch Plains, New Jersey - No building or structure shall be altered that would be in violation of this ordinance.

- 1949 Town of Huntington, New York - No building or structure shall be altered that would be in violation of this ordinance.

1960 Brookline, Massachusetts -

- If an alteration exceeds $50 \%$ of building value within a 12 month period, then the entire building shall conform to current code. 
- If an alteration falls between $25 \%$ and $50 \%$ of the building value within a 12 month period, then the altered sections must comply with the code.

- If an alteration is less than $25 \%$ of the building value within 12 month period, then the altered

- 1966 Los Angeles, California - Alterations must comply to the requirements of new buildings.

Notice the similarity of most of the old codes. This was probably due to the National Board of Fire Underwriters codes that were accepted and probably modified to each municipalities criteria.

The writer will give a few examples of cases where it was necessary to research the Building Department in order to determine the year of construction of the buildings involved in the following staircase accidents.

\section{Case Example \#1}

The Plaintiff fell walking down exterior cellar stairs. The stairs led from the sidewalk down to a court. Stairs were constructed of concrete and were the original construction. The stairs had handrail on one side. The handrail began on second riser down from the top and ended at third riser up from the bottom. The multiple dwelling building was constructed in 1929, and therefore, the building was constructed under the 1916 New York City Building Code as far as material and loads, and under the New York Tenement House Act regarding means of egress. The 1916 Building Code had an "exception" regarding means of egress in multiple dwellings.

The opposing expert cited the current 1968 New York City Building Code, the

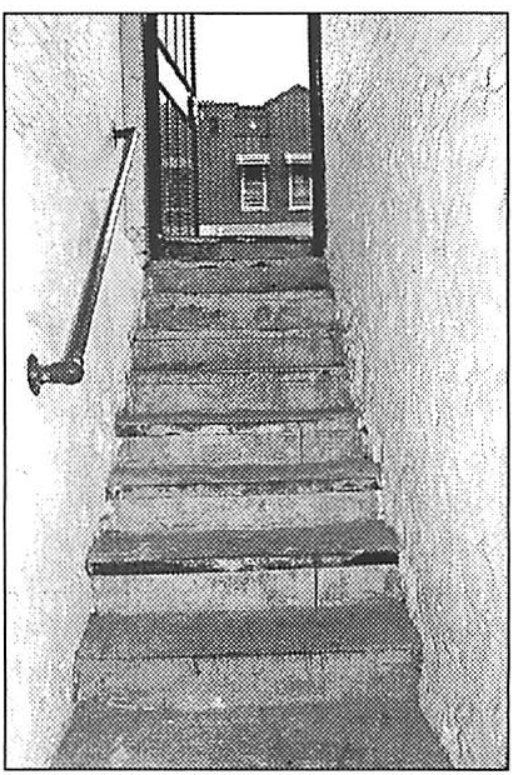

Case Example \#1 1938 New York City Building Code and the 1916 New York City Building Code. He also cited the current Multiple Dwelling Law in a supplemental expert disclosure, but he did not cite the Tenement House Act. The opposing expert did not perform a building history search, but threw in a "kitchen sink" of codes. Including Code of Federal Regulations (CFR) and architectural standards. 
The Plaintiff fell on bottom step and claimed that her heel got caught in a crack in the step.

The problem for the defense was that the handrail did not extend to bottom of stairs as required by the Tenement House Act. The best argument for the defense was that the Plaintiff's expert cited codes that were not in existence when building was constructed and therefore should be precluded from offering an opinion. The best argument for the plaintiff would have been that by any standards the steps were not maintained and that the owner had the obligation to maintain the steps to the code (Tenement House Act) to which it was built. This could have been the argument once the expert had been disclosed. Also, it could have been pleaded by the plaintiff that the condition was caused by the defendant because the original handrail had been replaced and that the replacement handrail was installed incorrectly.

\section{Case Example \#2}

The plaintiff fell down rear yard exterior cellar stairs while carrying a refrigerator. The stairs were constructed of concrete and were not the original construction. Most probably the stairs were reconstructed. The stairs had no handrails. The steps were irregular with varying riser heights and tread widths. The plaintiff, carrying the refrigerator down with a helper who was holding the top of the refrigerator while the plaintiff was holding the bottom of the refrigerator. Plaintiff mis-stepped and fell to bottom of the stairs and the refrigerator fell on his arm. The original structure was a two-family house that was converted to a three-family house under the Tenement House Act in 1928. Under Section 21, Stairways and Stairs of the Tenement House Act, it was

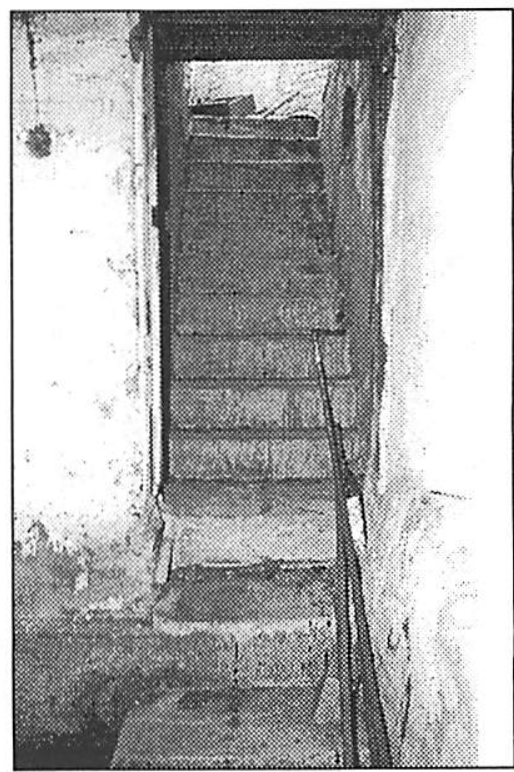

Case Example \#2 stated that all stairs be constructed with risers not more than eight inches (8") and tread widths not less than ten inches (10") except that in three-family and fourfamily converted dwellings the existing height of risers and dimensions of treads of stairs shall be accepted by the department.

The stairs had no handrail and was irregular and that made the stairs dangerous. However, the lack of a handrail was not the proximate cause of the fall. The irregular step geometry was probably the cause of the fall. But there was no 
code violation because the steps were accepted by the department, "as is". Therefore, the plaintiff could not cite a code violation. The opposing expert cited current 1968 Building Code for violations, which was not applicable.

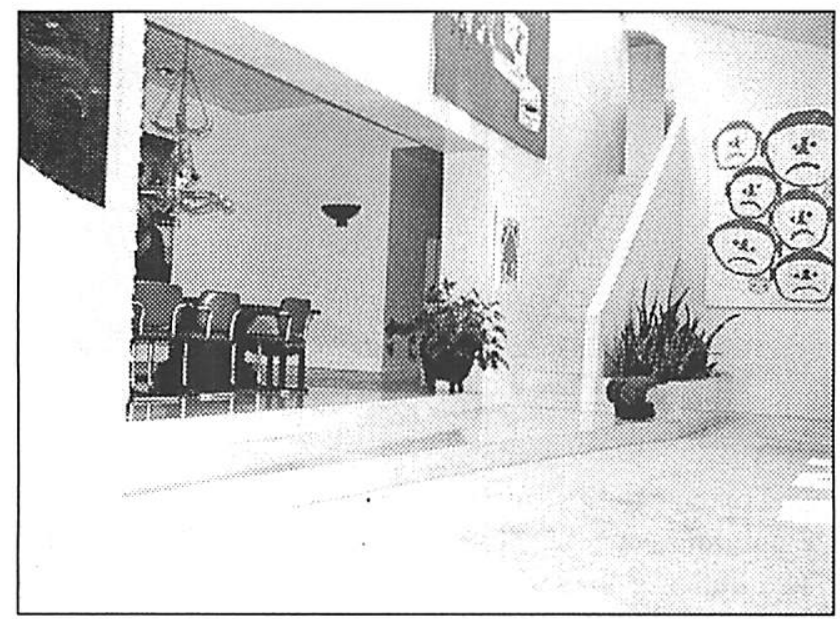

Case Example \#3

\section{Case Example \#3}

The plaintiff fell off of a split level in a duplex apartment. The living and dining rooms were at two (2) different levels. There were four (4) entrances to the dining area with two (2) steps up to the dining room level. The plaintiff was talking with owner of apartment and stepped backward off of the platform and incurred injuries. There was no guardrail surrounding dining area. The building was renovated to the current 1968 New York City Building Code. The New York State Multiple Dwelling Law, Section §52. Stairs, stated:

Section $\$ 52(8)$. The provisions of this section shall not apply to a stair within an apartment provided that each level of the apartment is provided with the required means of egress complying with the provisions of this article.

This was stating that as long as there were other means of egress from the dining area, split level platforms were acceptable. There were three (3) other means of egress to and from the dining area beside the split level entrance/exit. The opposing expert stated that the steps had a static coefficient of friction of 0.55 and that is why she tripped and fell. This was a ridiculous opinion because the plaintiff stated that she stepped off of the platform. 


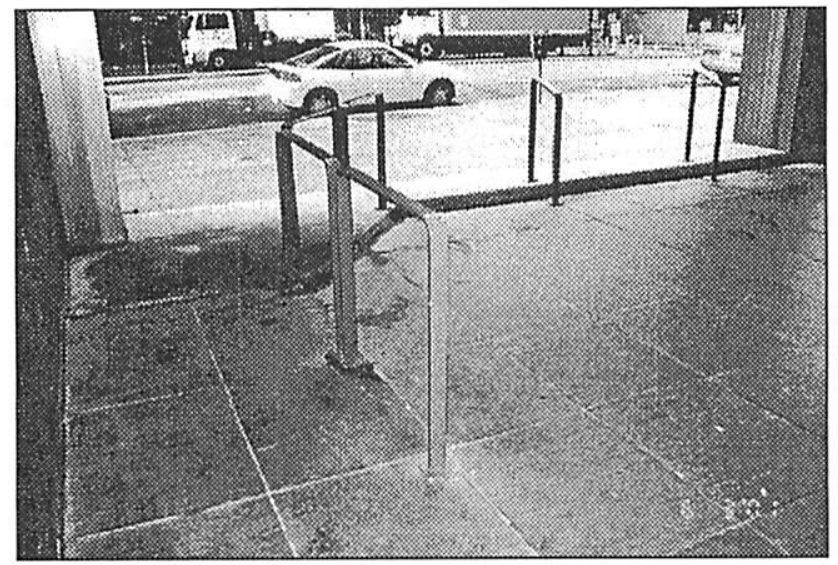

Case Example \#4

\section{Case Example \#4}

Plaintiff tripped on an exterior single step riser in building plaza. The building was an office building constructed in 1968 under the 1938 New York City Building Code. The building management could not locate the original plans, and they were not archived at the building department, to determine when the exterior handrails were installed. The building had four (4) entrances/exits. The 1938 Building Code provided a section for ornamental stairways which stated;

Service or ornamental stairways. Unenclosed service or ornamental stairways may be constructed under the following conditions;

1. Such stairways shall be so placed as not to obstruct or interfere with the functions or use of the required means of egress nor to be a part of such means of egress.

There were three (3) other means of egress from the building. It was also not clear whether the original architectural plans designated the plaza as an ornamental step. The opposing expert cited single step risers in lines of travel must be ramped from the 1968 Building Code which was not applicable.

\section{Case Example \#5}

The plaintiff tripped on a single step riser exiting a restaurant. The enclosure was for a sidewalk cafe, which was constructed several years prior to the accident, and the owner received a certificate of occupancy. The single step riser was approximately two feet (2') before the door as a pedestrian would exit. There was a "Directive" issued by the New York City Building Department that required that enclosed sidewalk cafes be constructed under the current (1968) building code. The building was constructed circa 1905 and therefore under the 1899 Building Code of the City of New York. The current code required the 


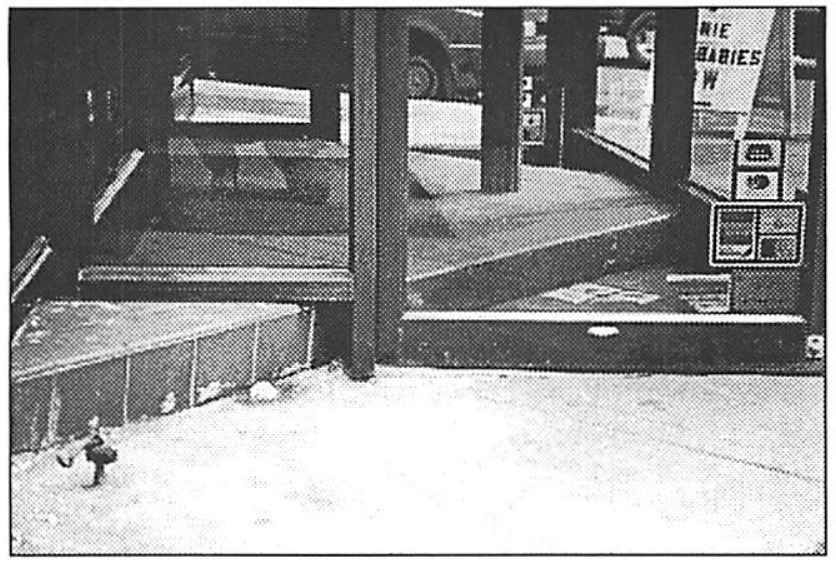

Case Example \#5

floor area to be the same on both sides of the door. The current code also required that there be no change in level along exit passageways. However, the current code allowed a step down from exit doors to the sidewalk of a maximum of seven and three-quarter inches (7-3/4").

Plaintiff's expert cited that the cafe enclosure violated the "no change in level" in a passageway, and that the single step riser was a violation of the current building code. In addition, plaintiff's expert stated that the exit door was improperly constructed, that the exit door should have been even, or co-linear, with the single step riser as allowed by the "exception" in the building code. The defendant's expert sited the 1938 Building Code for exits, and that the exit was proper.

\section{Conclusion}

When the forensic engineer investigates staircase accidents in buildings he should proceed and be aware of the following:

- Determine when the building was constructed.

- Determine the occupancy of the building, i.e.; commercial, public, dwelling, school, etc.

- Determine if there were any alterations and when and at what cost within 12 month period.

- If the alterations were performed, he must determine the cost of the alterations relative to the value of the building exclusive of the land.

- He must apply the correct building code and determine if that building code "excepts" the building in question. 
- He must determine if an exception was granted, e.g.; if a multiple dwelling law or tenement house law applied rather than a building code.

- If a railroad was involved, e.g.; plaintiff fell on platform stairs; railroads are not usually governed by the building code. He would need to go to the CFR Part 49 or Part 36.

- If the case involved a one or two-family dwelling, then these dwellings are usually not governed by the building code but under codes that apply to one and two-family dwellings.

- Local codes (city, town, village, etc.) usually have precedence over state codes provided they are more restrictive.

- State codes have precedence of federal codes provided they are more restrictive.

- Federal codes have precedence over standards provided they are more restrictive.

- Standards and custom and practice may have relevance if there are no codes or ordinances that apply.

- Check if there were any "Directives" issued by the building department obligating the owner to update his/her building. i.e.; New York City Local Law 10, required owners to check the facade of their buildings every 5 years by a registered architect or professional engineer.

\section{References}

1. Black's Law Dictionary, Sixth Edition, West Publishing Company, St. Paul, Minnesota. 